\title{
Pharmacognostical and phytochemical studies of Mollugo nudicaulis Lam.: A controversial plant origin ayurvedic drug
}

Goli Penchala Pratap*, Brahmanapalle Jyothi**, Mohd. Kashif Husain**, Vallepu Nagaraju*** and Gudivada Sudarsanam*** *National Research Institute of Unani Medicine for Skin Disorders, Hyderabad-500038, T.S., India

**Department of Botany, SPW Degree and P.G. College, Tirupati-517502, A.P., India

***Department of Botany, Sri Venkateswara University, Tirupati-517502, A.P., India

\section{Article Info \\ Article history \\ Received 5 September 2021 \\ Revised 28 October 2021 \\ Accepted 29 October 2021 \\ Published Online 30 December 2021}

\section{Keywords}

Mollugo nudicaulis Lam.

Parpataka

Pharmacognosy

Powder microscopy

Fluorescence studies HPTLC

\begin{abstract}
Mollugo nudicaulis Lam. of Molluginaceae is an important medicinal plant widely distributed throughout India, Pakistan and tropical Africa. The whole plant is used in the preparation of an Ayurvedic drugParpataka, which is controversial, as a good number of plants are used as Parpataka in different regions of India. The present communication deals to authenticate the species of $M$. nudicaulis through macroscopical, microscopical, preliminary phytochemical, physicochemical, fluorescence, and HPTLC studies. Microscopical studies of the root revealed the presence of 4 to 5 layered cortex with parenchyma cells. The xylem observed in tetrarch condition with no growth rings. The fibres are narrow and vessel elements noticed with short tails. The leaf was characterized with well differentiated mesophyll into palisade and spongy parenchyma cells. The vascular bundle was single, conjoint, collateral and top shaped. The calcium oxalate crystals were noticed abundantly in the mesophyll and druses in spongy mesophyll. The stomata were noticed as anomocytic type. Physicochemical values were recorded as; total ash (1.094 $\%)$, water-soluble ash $(1.46 \%)$, alkalinity of water soluble ash $(0.328 \mathrm{ml})$ and acid insoluble ash $(1.64 \%)$. The preliminary phytochemical screening revealed the existence of steroids, tannins, phenols, anthraquinones, alkaloids, flavonoids, terpenoids, coumarins and quinones in two solvent systems. The screenings of HPTLC showed the occurrence of noteworthy phytoconstituents with $R_{f}$ values. The pharmacognostical screening of $M$. nudicaulis is very beneficial for the comparison, authentication of the original drug and to maintain the quality and purity of the plant material used in various Ayurvedic formulations.
\end{abstract}

\section{Introduction}

'Parpataka' is an important drug, used in the Indian systems of medicine (ISM). It is one of the prominent drugs in Ayurveda, which is mainly used to treat fevers. The drug is bitter, diuretic, digestive, anthelmintic and relieves constipation (Nadkarni, 1996). The drug is used in the management of Rakta Pitta (hemorrhage), Brama (giddiness), Trishna (thirst) and Daaha (burning sensation) (Lakshmipati, 1973).

The therapeutic value of the 'Parpataka' plant has been reported by many workers. The whole plant is considered as pectoral, used in muscular atrophy and whooping cough (Kirtikar and Basu, 1987). The plant leaves are applied externally to remove the pus from boils (Anonymous, 1962; Yoganarasimhan, 2000). The grounded leaves alongwith garlic and pepper is consumed internally to treat polydipsia (Sudarsanam, 1987).

Despite of its multiple uses, the drug is somewhat controversial in identity because in practice many plants are used and marketed with the same name 'Parpataka' in various local markets of the

Corresponding author: Dr. Mohd. Kashif Husain

Scientist, National Research Institute of Unani Medicine for Skin Disorders, Hyderabad-500038, T.S., India

E-mail: kashifptc@gmail.com

Tel.: +91-7382189745

Copyright (c) 2021 Ukaaz Publications. All rights reserved.

Email: ukaaz@yahoo.com; Website: www.ukaazpublications.com country. As per the Ayurvedic Formulary of India, the accepted source of the drug is Fumaria indica (Hassk.) Pug. (Anonymous, 1978). The other plants which are used as Parpataka are; Glossocardia bosvallea (L.f.) DC., Polycarpaea corymbosa (L.) Lam., Rungia repens (L.) Nees., Glinus oppositifolius (L.) Aug. DC., Hedyotis corymbosa (L.) Lam., and Mollugo cerviana (L.) Ser. (Chunekar, 1999; Bapalal, 1985).

It was found during the search of crude drugs from local market of Tirupati that a single medication locally called as 'Parpatakamu' (Telugu) was frequently used as a 'Parpataka' by traditional Ayurveda and Siddha practitioners at different places of South India. The drug was botanically identified as Mollugo nudicaulis and the same has further been confirmed by local Ayurvedic Physicians, who used it as 'Parpataka'. The plant is found to be quite different from earlier reported species of 'Parpataka'.

To the best of our knowledge, no pharmacognostical work has been carried out on M. nudicaulis. Considering the importance of the species, the present pharmacognostical study was carried out to identify the local market sample of 'Parpataka' on the basis of macro, microscopic and physicochemical parameters, so that the drug could be differentiated from the other reported botanical sources. 


\section{Materials and Methods}

\subsection{Plant collection and identification}

The healthy plant material of $M$. nudicaulis was collected from Sri Venkateswara University (SVU) campus, Tirupati, Andhra Pradesh. The specimen was identified and authenticated by local and regional floras (Gamble, 1936; Rangacharyulu, 1991). The herbarium of voucher specimen (Field Book No.: G.S. 1990) submitted in the Department of Botany, S.V. University for future reference.

\subsection{Macroscopic examination and organoleptic properties}

The plant of M. nudicaulis was visually examined for macroscopic characters. The organoleptic properties such as odour, colour, touch and taste of the plant material was observed and noted as per standard procedure (Johansen, 1940; Pratap et al., 2014-2; Jyothi et al., 2020; Kumari et al., 2020).

\subsection{Anatomical evaluation}

The anatomical evaluation of root and leaf was done by using the standard process of sectioning, powder microscopy, maceration, leaf clearing and venation studies (Johansen, 1940; Jyothi et al., 2020; Pratap et al., 2014-1).

\subsection{Physicochemical studies}

The physicochemical studies were assessed as per standard methods on the basis of ash values, extractive values in different solvents and calculating the weight loss on drying (Pratap et al., 2014; Kumari et al., 2020, Pande et al., 2018; Jyoti et al., 2018; Yadav and Singh, 2018)

\subsection{Fluorescence studies}

The fluorescence studies were done by treating the plant material with different reagents followed by observation in terms of color changes under visible light and UV chambers (Jyothi et al., 2020; Pratap et al., 2014-2; Kumari et al., 2020).

\subsection{Preliminary phytochemical studies}

The powdered plant material was subjected to different types of analytical test for the identification of secondary metabolites like; alkaloids (Dragendorff's and Mayer's tests), triterpenes (Libermann Burchard's test), flavonoids (Aluminium chloride test), anthraquinones (Borntrager's test), polyphenols (Ferric chloride test), sterols (Salkowski's test), coumarins (Lactone test), saponins (Foam test) and tannins (Gelatin test) (Harborne, 1973; Jyoti et al., 2018; Ngameni et al., 2013; Pande et al., 2018; Pratap et al., 2014; Pratap et al., 2012; Poumale et al., 2013; Wansi et al., 2013; Yadav and Singh, 2018)

\subsection{Procedure for HPTLC analysis}

Alcoholic extract of the powdered drug was used for thin-layer chromatography using a solvent system; toluene: ethyl acetate (6:4), which was saturated for $45 \mathrm{~min}$ in CAMAG® Flat Bottom Chamber of $10 \times 10 \mathrm{~cm}$. The extract was applied manually on TLC silica gel 60 F254 aluminum coated plates (Merck, KgaA, Germany) and run up to $8 \mathrm{~cm}$. These plates were kept in HPTLC instrument Desaga Sarstedt Gruppe (Germany). The plates were observed under ultraviolet (UV) light at $366 \mathrm{~nm}, 254 \mathrm{~nm}$ and daylight. UV cabinet was arranged with imaging and camera set up with remote shooting. The retention factor $\left(\mathrm{R}_{\mathrm{f}}\right)$, area, the height of the peak of the developed bands were recorded (Pratap et al., 2012; Kumari et al., 2020).

\section{Results}

\subsection{Taxonomy}

Mollugo nudicaulis Lam. Encycl. 4: 234. 1797; Wight \& Arn. Prodr. Fl. Ind. orient. 43. 1834; Hook.f. Fl. Brit. India 2: 664. 1879; Gamble, Fl. Madras 1: 553 (390). 1919; Matthew, Mat. Fl. Tamil Nadu Carnatic 225. 1981 \& Ill. Fl. Tamil Nadu Carnatic t. 311. 1982.

M. nudicaulis is an erect annual herb. The leaf is radical, spathulate, $4 \times 2-4 \times 1-2 \mathrm{~cm}$, membranous, glabrous, base attenuate, margin entire, apex retuse-obtuse, petiole up to $1 \mathrm{~cm}$. Flowers white, in many peduncled, polychasial cymes arising from the base. The length of peduncle is up to $8 \mathrm{~cm}$. The branches are leafless, angular, bearing membranous bracts at the nodes, bracts up to $1 \mathrm{~mm}$, pedicel up to $4 \mathrm{~mm}$. Flowers $3 \mathrm{~mm}$, across. Sepals 5, white, elliptic, $3 \mathrm{~mm}$, hooded. Petals are absent. Stamens 3-5, filaments up to $1.5-2 \mathrm{~mm}$. Ovary oblong, 3 lobed, 3-celled, styles 3, capsules ellipsoid, or nearly globose, up to $2 \mathrm{~mm}$ brown, seeds many, black, reniform, granular (Figure1).

\subsection{Macro characters of root}

The roots are long, light cream colored with few lateral roots which can be broken easily (Figure1). The odor was pleasant and slightly bitter in taste (Table 1).

Table 1: Powder characteristics of the whole plant of $M$. nudicaulis

\begin{tabular}{|l|l|l|l|}
\hline Colour & Appearance & Odour & Taste \\
\hline Pale brown & Fine powder & Agreeable odour & Slightly bitter \\
\hline
\end{tabular}

3.3 Microscopical characters of root

Transverse section (T.S.) of the root showed periderm, cortex and large vascular cylinder (Figure 2.1).

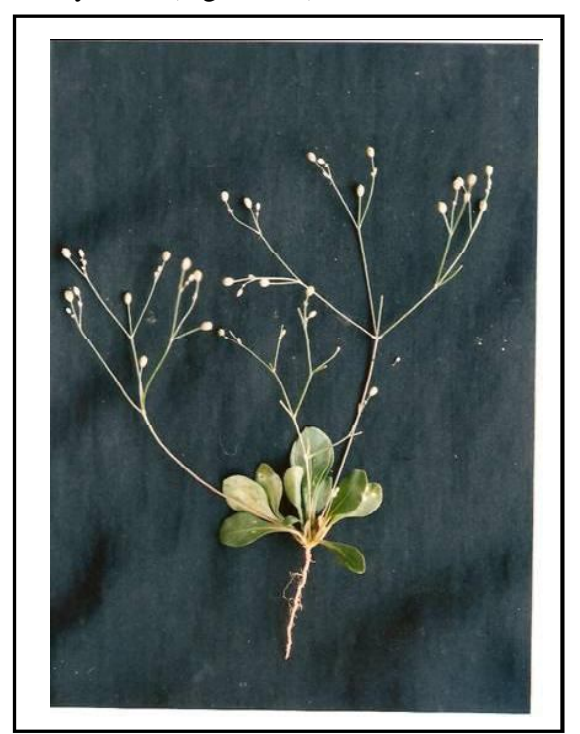

Figure 1: Mollugo nudicaulis Lam. 
Periderm is 2 to 3 layered; cortex is made up of 4 or 5 layered parenchyma cells. Secondary phloem is thin and continuous. Secondary xylem is nearly $900 \mu \mathrm{m}$ in diameter. It consists of thin xylem rays of one cell wide, narrow thick-walled vessels and xylem fibres. Vessels are diffuse in distribution; they are circular, mostly solitary or may be in radial multiples, widest vessel is $50 \mu \mathrm{m}$ in diameter. Xylem fibres are thick walled and lignified. Primary xylem is tetrarch and consists of radial rows of small xylem elements (Figure 2.2).

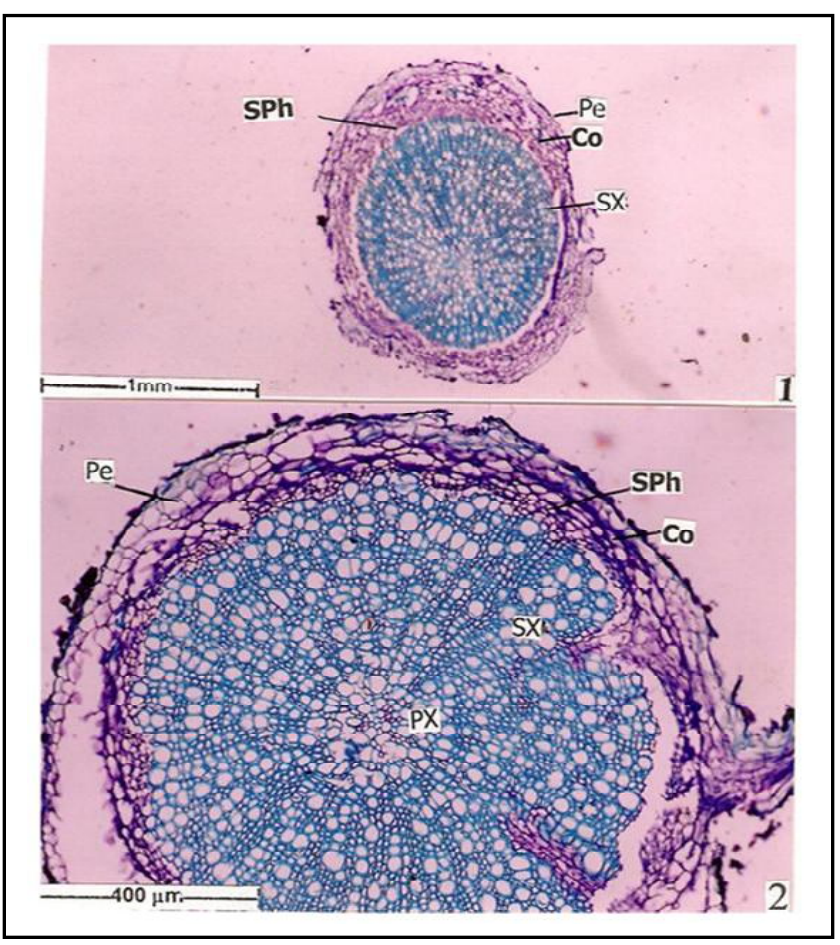

Figure 2: T.S. of root; 1: Microscopical characters of root. 2: T.S. of entire root (enlarged view). Pe: Periderm; Co: Cortex; SPh: Secondary phloem; SX: Secondary xylem; PX: Primary xylem.

Diagnostic characters of root

1. Periderm 2 or 3 layered, not well developed.

2. Cortex in 4 to 5 layered parenchyma cells.

3. Secondary phloem thin and continuous.

4. Xylem-tetrarch condition.

5. Growth rings absent.

6. Presence of narrow elongated fibres and vessel elements with short tails.

\subsection{Macroscopical characters of leaf}

Leaves radical spathulate, entire, acute $2-3 \times 1.2 \mathrm{~cm}$, membranous, glabrous, base attenuate, petiole $1 \mathrm{~cm}$, slightly bitter and smell pleasing.

\subsection{Microscopical characters of leaf}

Leaf has fairly prominent midrib and uniformly thin, smooth and even lamina (Figure 3). T.S. of the leaf shows the epidermis, mesophyll and vascular bundle. Lateral veins do not project much beyond the leaf surface. Midrib is nearly $650 \mu \mathrm{m}$ thick in vertical axis. It has a short, blunt adaxial hump and narrowly hemispherical adaxial body. The adaxial midrib consists of compactly arranged thin-walled parenchyma cells. Palisade tissue of the lamina extends as transcurrent band along the adaxial hump. Vascular bundle is single conjoint, collateral and top-shaped. It consists of a cone of xylem elements and thin arc of phloem (Figure 3.2). Vascular bundle is surrounded by a ring of hyaline bundle sheath cells.

\subsection{Lamina}

It is about $300 \mu \mathrm{m}$ thick. Abaxial epidermis is made up of different size and shape of cells. Adaxial epidermis also made up of unequal size of cells (Figure 3:1-3). Mesophyll is well differentiated into an adaxial layer of palisade parenchyma and abaxial layer of spongy parenchyma. Palisade parenchyma cells are cylindrical and compactly arranged in a single layer and $90 \mu \mathrm{m}$ in length. Spongy parenchyma is 4 or 5 layered and loosely arranged (Figure 3.3). Vascular bundle of the lateral vein has a small core of xylem and a phloem mass forming a conjoint, collateral vascular bundle and surrounded by a whorl of bundle sheath cells.

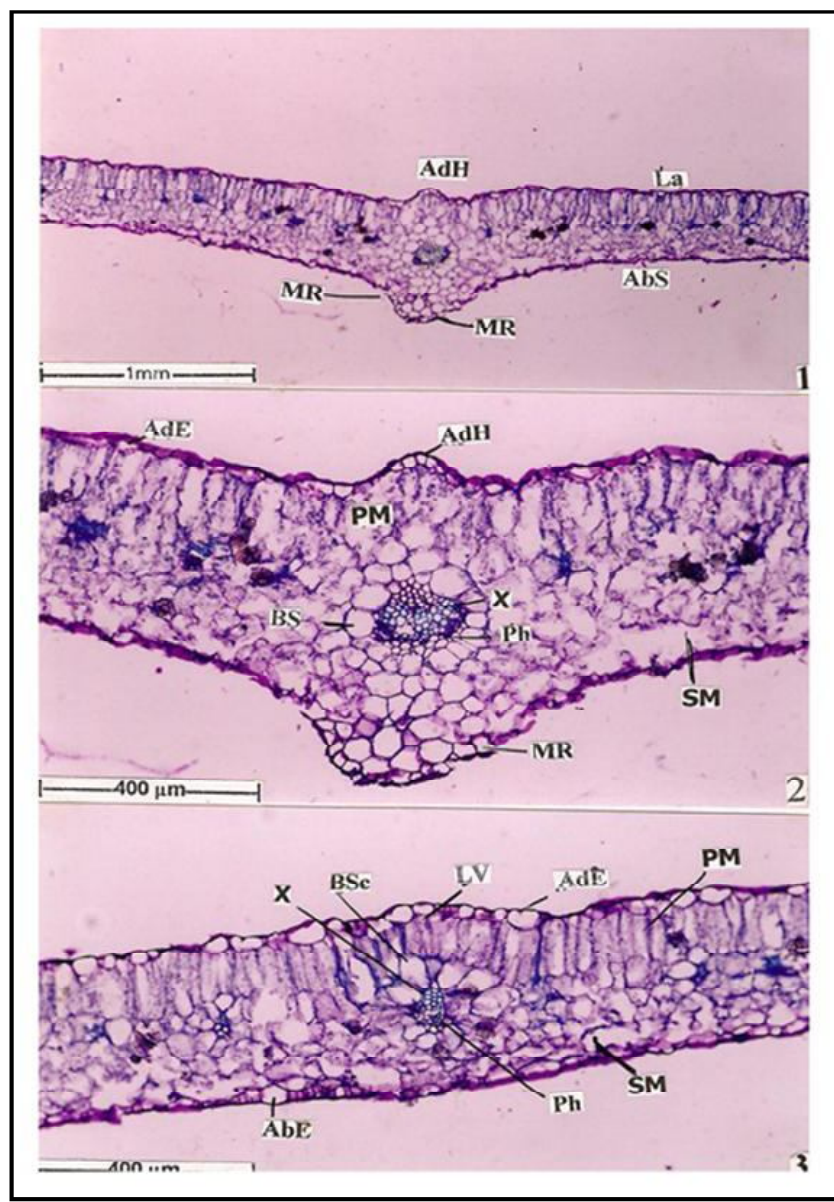

Figure 3: T.S. of the leaf; 1: T.S. of leaf through mid rib with lamina 2: Enlarged midrib 3: T.S. of leaf through lateral vein with lamina. AdH: Adaxial hump; La: Lamina; AbS: Abaxial surface; MR: Midrib; AdE: Adaxial epidermis; PM: Palisade mesophyll; X: xylem; Ph: phloem; BS: Bundle sheath; SM: Spongy mesophyll; LV: Lateral vein; BSC: Bundle sheath cells. 


\subsection{Crystals}

Calcium oxalate crystals abundant in the mesophyll (Figure 4). Crystals are mostly druses, present in the spongy mesophyll (Figure 4:1-3) or in the epidermal cells (Figure 4.3). The druses are up to $50 \mu \mathrm{m}$ thick. The prismatic crystals are cuboidal or rectangular (Figure 4:2-3).

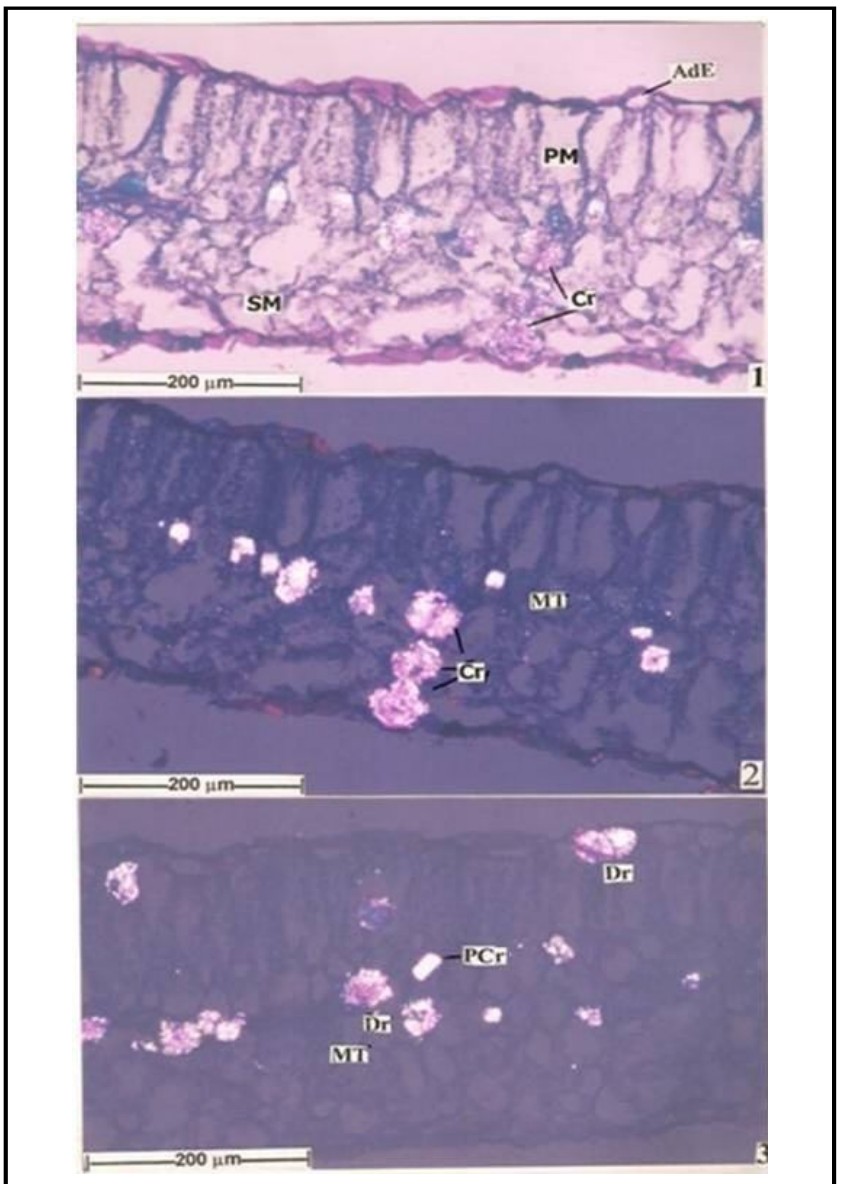

Figure 4: Crystal distribution in mesophyll; 1. T.S. of leaf under bright field microscopy 2-3. T.S. of leaf under polarized light microscope.

AdE: Adaxial epidermis; PM: Palisade mesophyll; SM: Spongy mesophyll; Cr: Crystal; MT: Mesophyll tissue; Dr: Druces; PCr: Prismatic crystals.

\subsection{Basal part of the leaf}

It has thick, prominent midrib and thick glabrous lamina. Midrib is about $1 \mathrm{~mm}$ thick and has prominent adaxial hump and wider, semicircular abaxial part. Ground tissue is homogenous and made up of parenchyma. Vascular strand is arc shaped, conjoint and collateral (Figure 5:1-2)

\subsection{Venation pattern}

In surface view, the lateral veins and veinlets were found uniformly thin. They form wide distinct vein-islets of varying shape and size. Short or long, thin less prominent vein-terminations are seen in most of the islets. The terminations are unbranched, occasionally forked once at tip. Large druses of calcium oxalate crystals are abundant in the leaf (Figure 6.1).

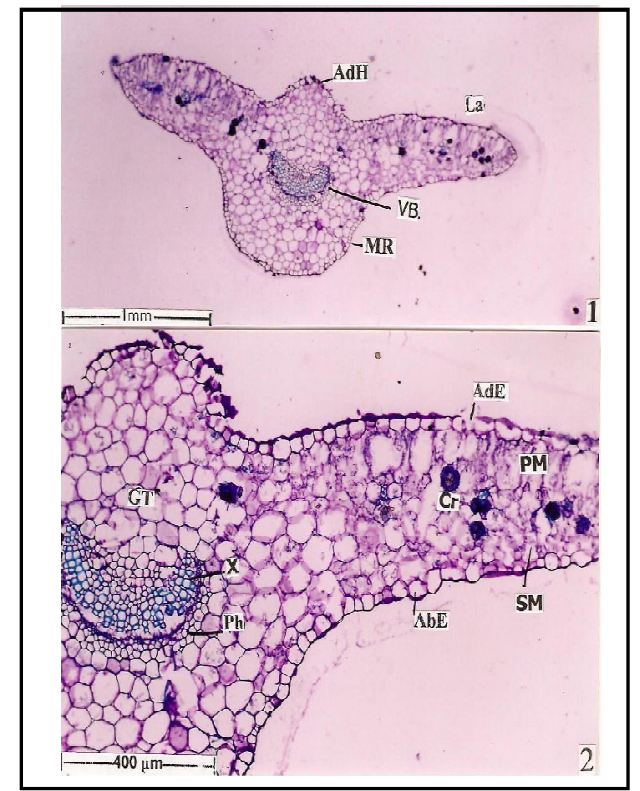

Figure 5: Microscopical characters of basal part of leaf; 1: T.S. of leaf-Entire view 2: T.S. of leaf-an enlarged portion.

AdH: Adaxial hump; La: Lamina; VB: Vascular bundle; MR: Midrib; AdE: Adaxial epidermis; PM: Palisade mesophyll; SM: Spongy mesophyll; X: xylem; Ph: phloem; GT: Ground tissue; AbE: Abaxial epidermis; Cr: Crystal.

\subsection{Stomata}

Stomata found on both the upper and lower epidermis. In surface view, the stomata were either elliptical or circular. They were exclusively anomocytic type, lacking distinct subsidiary cells. The epidermal cells are lobed and their anticlinal walls were thin and wavy (Figure 6.2).

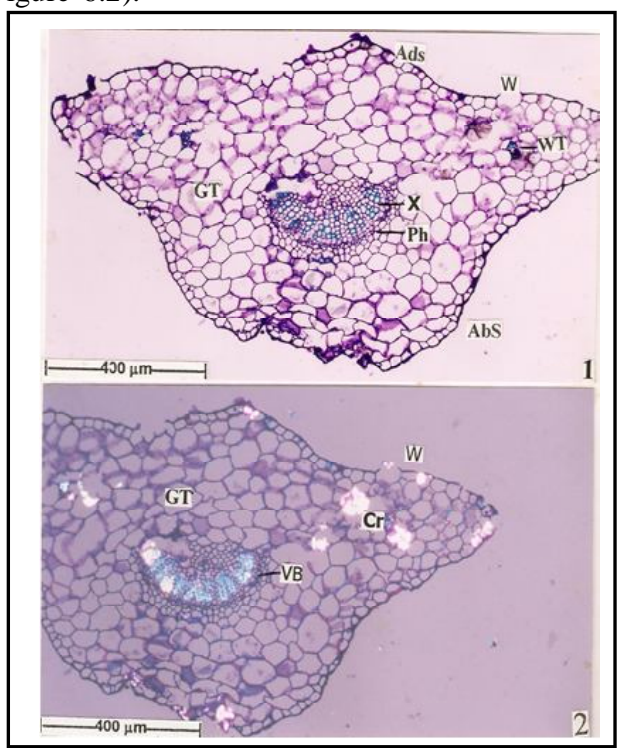

Figure 6: Microscopical characters of the petiole; 1: T.S. of petiole-entire view 2: T.S. of petiole-entire view (under polarized light microscope showing crystals). AdS: Adaxial surface; Abs: Abaxial surface; W: Wing; WT: Wing tissue; X: xylem; Ph: phloem; GT: Ground tissue; VB: Vascular bundle. 


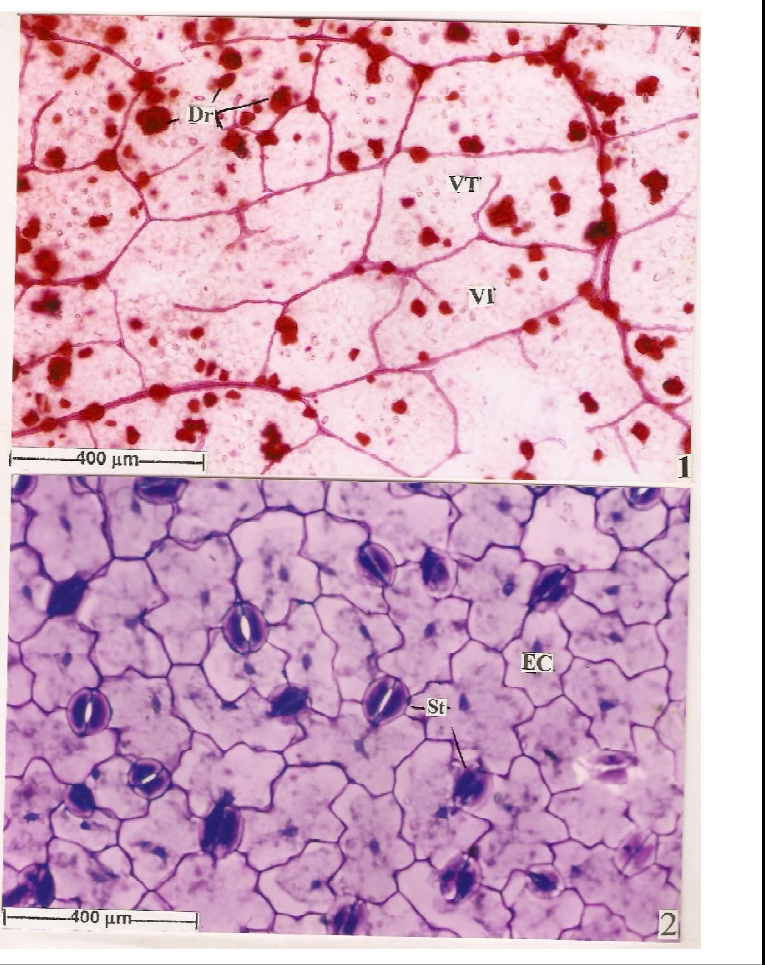

Figure 7: Venation pattern and stomatal morphology; 1: Vein -islets and vein-terminations 2: Abaxial epidermis with stomata.

Dr: Druces; VT: Vein-termination; EC: Epidermal cells; St: Stomata.

\subsection{Petiole}

It was found thick in the middle with short thick wings (Figure 7.1). It was $750 \mu \mathrm{m}$ thick in the median part, wings were $250 \mu \mathrm{m}$ thick. The adaxial part of the petiole is slightly raised and abaxial part is broadly semicircular. Ground tissue of the midrib and wings consists of homogenous, thin walled, compactly arranged parenchymatous cells. Vascular bundle was single collateral, bowl shaped and consists of parallel rows of small angular xylem and a thin arc of phloem. Calcium oxalate druses were observed in the ground tissue as well as in the vascular tissue (Figure 7.2).

Leaf-diagnostic characters

1. Mesophyll well differentiated into palisade and spongy parenchyma cells.

2. Vascular bundle-single, conjoint, collateral and top shaped.

3. Calcium oxalate crystals are abundant in mesophyll.

4. Crystals are of large druses in spongy mesophyll.

5. Presence of anomocytic type of stomata.

\subsection{Maceration}

The maceration of the whole plant showed the vessel elements narrow with or without tails. The root vessel elements were wider and short, with short tails (Figure 8:1-2) or tailless
(Figure 8:3). Stem vessel elements mostly were found mostly tailed and narrow (Figure 8:2). Perforation plates were simple, oblique. Lateral wall pits elliptical and dense; $250-400 \mu \mathrm{m}$ long and 25-30 $\mu \mathrm{m}$ wide.

\subsection{Fibres}

Narrow and wide fibres both were seen, wide fibres showed thin walls, wide lumen up to $280-350 \mu \mathrm{m}$ long and $20 \mu \mathrm{m}$ wide. The narrow fibres were found $350-500 \mu \mathrm{m}$ long and $10 \mu \mathrm{m}$ wide. In root, only narrow fibres were observed and they were 650-950 $\mu \mathrm{m}$ long and $5 \mu \mathrm{m}$ wide. The root vessels were 250-500 $\mu \mathrm{m}$ long and $25 \mu \mathrm{m}$ wide (Figure 8: 1-2).

\subsection{Epidermis}

The epidermal cells were highly lobed and amoeboid in outline. The cells were fairly thick walled, and stomata were exclusively anomocytic with guard cells $40 \times 20 \mu \mathrm{m}$ (Figure 9:1).

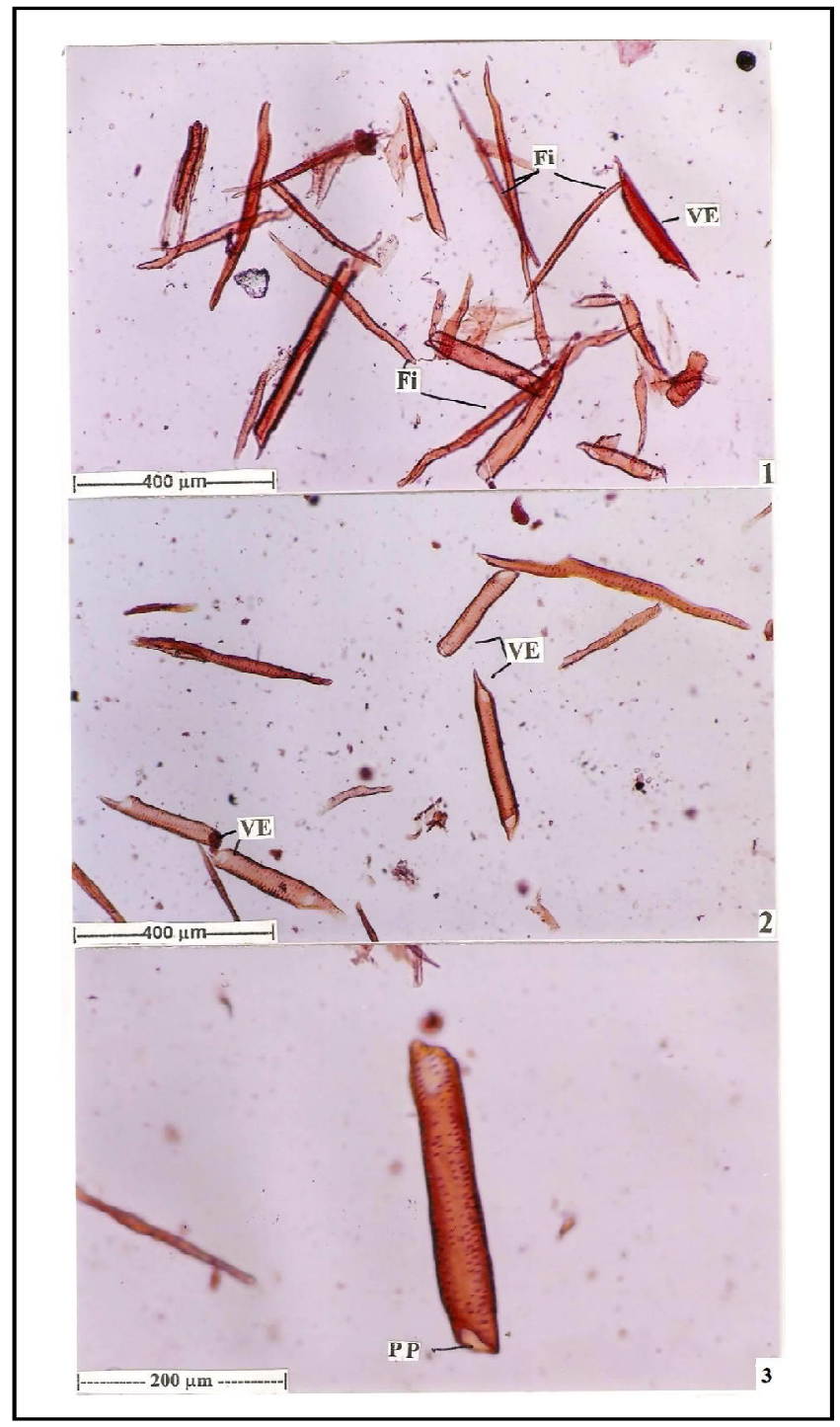

Figure 8: Whole plant macerate; 1: Stem macerate, 2: Root macerate 3: Tailless xylem elements Fi-Fibres; VEVessel elements; PP-Perforation plates. 


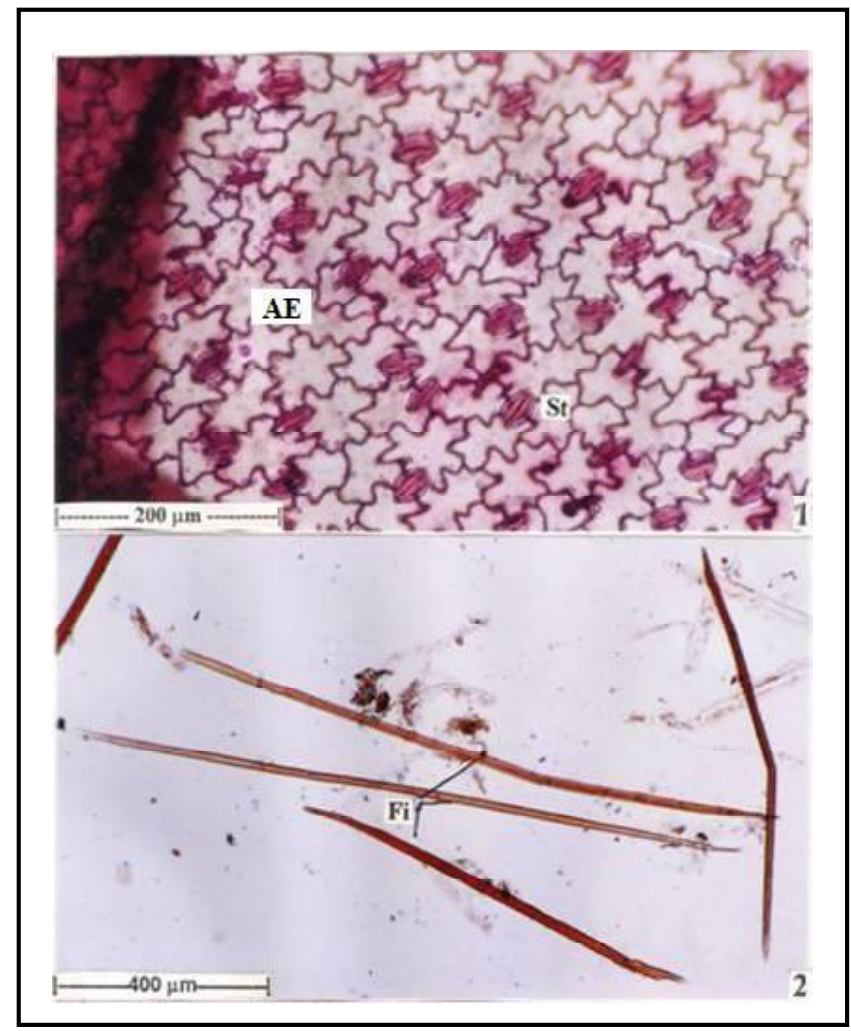

Figure 9: 1-2: Macerates of the whole plant St-Stomata; Fifibres; AE-Amoeboid shaped epidermal cells.

\subsection{Organoleptic characters}

The characters like taste, sight, smell, and touch of the given plant material are summarized in Table 1.

\subsection{Powdered drug behavior with different chemical reagents}

The powder was treated with normal water and different reagents like $\mathrm{NaOH}$ and $\mathrm{H}_{2} \mathrm{SO}_{4}$. The observations are summarized in Table 2 .

Table 2: Powdered drug analysis of $M$. nudicaulis

\begin{tabular}{|l|c|}
\hline Treatment & $\begin{array}{c}\text { Observation } \\
\text { (Whole plant) }\end{array}$ \\
\hline Powder treated with water & $\begin{array}{c}\text { Non-sticky } \\
\text { Powder shaken with water } \\
\text { Powder treated with 5\% NaOH like froth } \\
\text { aqueous }\end{array}$ \\
$\begin{array}{l}\text { Powder treated with } 60 \% \text { sulphuric } \\
\text { acid }\left(\mathrm{H}_{2} \mathrm{SO}_{4}\right) \text { aqueous }\end{array}$ & Brown \\
$\begin{array}{l}\text { Powder pressed between filter paper } \\
\text { for } 24 \text { hours }\end{array}$ & No oil stain \\
\hline
\end{tabular}

\subsection{Physicochemical analysis}

Ash and extractive values of the drug are summarized in Table 3 and Table 4. It gives an idea of the earthy matter or the inorganic composition and other impurities present along with the drug.
Table 3: Ash values (M. nudicaulis)

\begin{tabular}{|c|c|c|c|}
\hline $\begin{array}{c}\text { Total (\%) } \\
\text { ash }\end{array}$ & $\begin{array}{c}\text { Water soluble } \\
\text { ash (\%) }\end{array}$ & $\begin{array}{c}\text { Alkalinity of } \\
\text { water soluble } \\
\text { ash (ml) }\end{array}$ & $\begin{array}{c}\text { Acid } \\
\text { insoluble } \\
\text { ash (\%) }\end{array}$ \\
\hline 1.94 & 1.46 & 0.3282 & 1.64 \\
\hline
\end{tabular}

Table 4: Extractive values (M. nudicaulis)

\begin{tabular}{|c|c|c|c|}
\hline $\begin{array}{c}\text { Alcohol } \\
\text { soluble } \\
\text { extract } \\
(\% \mathbf{w} / \mathbf{w})\end{array}$ & $\begin{array}{c}\text { Water } \\
\text { soluble } \\
\text { extract } \\
(\% \mathrm{w} / \mathrm{w})\end{array}$ & $\begin{array}{c}\text { Hexane } \\
\text { soluble } \\
\text { extract } \\
(\% \mathrm{w} / \mathrm{w})\end{array}$ & $\begin{array}{c}\text { Chloroform } \\
\text { soluble } \\
\text { extract } \\
(\% \mathrm{w} / \mathbf{w})\end{array}$ \\
\hline 1.96 & 3.09 & 1.15 & 0.7833 \\
\hline
\end{tabular}

3.18 Fluorescence analysis

Fluorescence is an important parameter for pharmacognostical evaluation. The phenomenon exhibited by different chemical constituents present in the plant material. Results of the fluorescence analysis of the powdered drug with $\mathrm{NaOH}, \mathrm{HNO}_{3}, \mathrm{H}_{2} \mathrm{SO}_{4} \mathrm{FeCl}_{3}$, picric acid and acetic acid gave different characteristic colour under the ordinary light and ultraviolet (UV) light at 254 and $366 \mathrm{~nm}$. The results of fluorescence analysis are summarized in Table 5.

Table 5: Fluorescence analysis of powdered drug (M. nudicaulis)

\begin{tabular}{|c|c|c|c|}
\hline \multirow[t]{2}{*}{ Experiments } & \multirow{2}{*}{$\begin{array}{l}\text { Visible } \\
\text { Day light }\end{array}$} & \multicolumn{2}{|c|}{ UV Light } \\
\hline & & $254 \mathrm{~nm}$ & $366 \mathrm{~nm}$ \\
\hline Drug powder & Pale brown & Pale green & Brown \\
\hline $\begin{array}{l}\text { Drug powder }+1 \mathrm{~N} \\
\mathrm{NaOH} \text { (aq.) }\end{array}$ & Brown & Black & Black \\
\hline $\begin{array}{l}\text { Drug powder }+1 \mathrm{~N} \\
\mathrm{NaOH} \text { (alc.) }\end{array}$ & Brown & $\begin{array}{l}\text { Yellowish } \\
\text { green }\end{array}$ & $\begin{array}{l}\text { Pale } \\
\text { green }\end{array}$ \\
\hline Drug powder $+1 \mathrm{~N} \mathrm{HCl}$ & Brown & Black & Black \\
\hline $\begin{array}{l}\text { Drug powder }+50 \% \\
\mathrm{H}_{2} \mathrm{SO}_{4}\end{array}$ & $\begin{array}{l}\text { Reddish } \\
\text { brown }\end{array}$ & $\begin{array}{l}\text { Yellowish } \\
\text { green }\end{array}$ & $\begin{array}{l}\text { Pale } \\
\text { green }\end{array}$ \\
\hline $\begin{array}{l}\text { Drug powder }+50 \% \\
\mathrm{HNO}_{3}\end{array}$ & Orange & $\begin{array}{l}\text { Yellowish } \\
\text { green }\end{array}$ & Black \\
\hline $\begin{array}{l}\text { Drug powder }+ \text { Picric } \\
\text { acid }\end{array}$ & $\begin{array}{l}\text { Dark olive } \\
\text { (green) }\end{array}$ & $\begin{array}{l}\text { Yellowish } \\
\text { green }\end{array}$ & Green \\
\hline $\begin{array}{l}\text { Drug powder + Acetic } \\
\text { acid }\end{array}$ & Brown & Pale green & Black \\
\hline $\begin{array}{l}\text { Drug powder }+ \text { Ferric } \\
\text { chloride }\end{array}$ & $\begin{array}{l}\text { Dark olive } \\
\text { (green) }\end{array}$ & Pale green & Black \\
\hline $\begin{array}{l}\text { Drug powder }+\mathrm{HNO}_{3} \\
+\mathrm{NH}_{3}\end{array}$ & $\begin{array}{l}\text { Reddish } \\
\text { orange } \\
\text { precipitate }\end{array}$ & $\begin{array}{l}\text { Yellowish } \\
\text { green }\end{array}$ & Green \\
\hline
\end{tabular}

\subsection{Preliminary phytochemical studies}

The preliminary phytochemical screening was carried out using the methanolic and aqueous extracts of the whole plant to determine the presence of different types of chemical constituents, which are mainly responsible for various therapeutic effects. Therefore, the extracts were analyzed for detection of alkaloids, flavonoids, terpenoids, steroids, tannins, phenols, anthraquinones, coumarins and quinones in two solvent systems. Presence and absence of different phytoconstituents are summarized in Table 6 . 
Table 6: Qualitative phytochemical screening of methanol and aqueous extracts of the whole plant of M. nudicaulis

\begin{tabular}{|l|c|c|c|c|c|c|c|c|c|}
\hline Name of the Compound & Alkaloids & Flavonoids & Terpenoids & Steroids & Tannins & Phenols & Anthraquinones & Coumarins & Quinones \\
\hline Aqueous extract & + & - & + & - & - & + & - & + & + \\
\hline Methanolic extract & + & + & + & + & + & + & + & + & + \\
\hline
\end{tabular}

\subsection{HPTLC profile}

Leaf and root extracts of the samples were spotted in triplets on the silica gel "G" plate shown in the figures. These plates were developed using the mobile phase as: Toluene: Ethyl acetate $(6: 4)$. Various spots were identified under UV light at $366 \mathrm{~nm}, 254 \mathrm{~nm}$ and visible light (Figures 10 and 12). Different $\mathrm{R}_{\mathrm{f}}$ values are summarized in the Tables 7 and 8 . The densitograms were developed for the leaf and root powders of M. nudicaulis plant (Figures 11 and 13).

TLC studies of the leaf powder showed ten major spots under UV light (366) $\mathrm{nm}$ with the $\mathrm{R}_{\mathrm{f}}$ values as; 0.04, 0.22, 0.33, 0.39 (All blue), 0.47 (light blue), 0.55 (red), 0.63, 0.66, 0.90 (All blue), 0.93 (red). While under UV light $(254 \mathrm{~nm})$ showed four spots with the $\mathrm{R}_{\mathrm{f}}$ values as; 0.04 (black), 0.22 (blue), 0.33 (green), 0.63 (light blue). Three spots with $R_{f}$ values: 0.04, 0.22, 0.33 (All yellow) were found under iodine vapours.

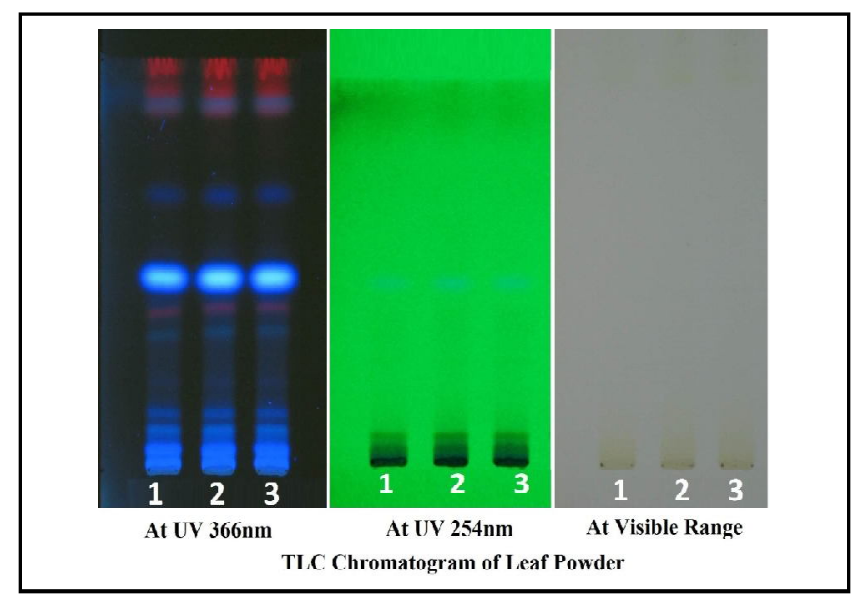

Figure 10: TLC chromatogram of the leaf powder.

TLC studies of the root powder showed ten major spots under UV light at $366 \mathrm{~nm}$ with the $\mathrm{R}_{\mathrm{f}}$ values as: 0.00 (brown), 0.09, 0.16, 0.21, 0.27, 0.43, 0.56, 0.64, 0.75, 0.88 (all red), 0.47 (light blue), 0.55 (red), 0.63, 0.66, 0.90 (all blue), 0.93 (red). While, under UV light at $254 \mathrm{~nm}$ showed five spots with $\mathrm{R}_{\mathrm{f}}$ values as; 0.00, 0.21, $0.27,0.88$ (all black). Eight spots with the $\mathrm{R}_{\mathrm{f}}$ values $(0.00,0.09$, $0.21,0.27,0.35,0.43,0.75,0.88$ (all yellow) were observed under iodine vapours.

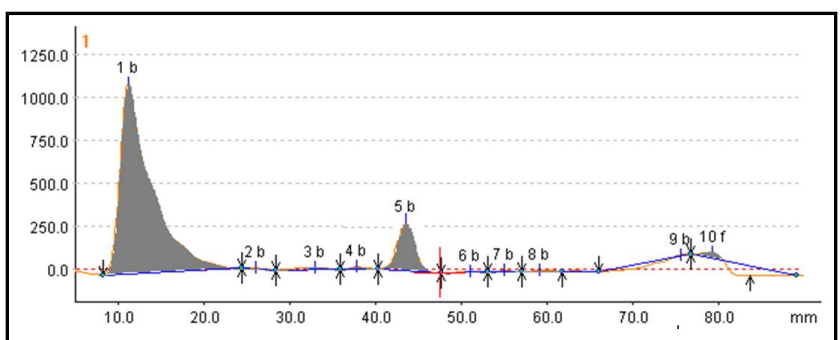

Figure 11: Densitogram showing the separation of peaks of leaf powder.
TLC plates were subjected to the HPTLC instrument to record the densitograms, in which different peaks were observed for the spots that appeared in the TLC plates. Each peak area was recorded and the corresponding data for peak areas as detected in HPTLC densitogram are presented in Figure 11 and Figure 12.

Table 7: Peak list and densitogram of leaf powder of M. nudicaulis at $366 \mathrm{~nm}$ UV light with $R_{\mathrm{f}}$ values of the spots

\begin{tabular}{|c|l|l|c|c|c|}
\hline $\begin{array}{c}\text { Peak } \\
\text { No. }\end{array}$ & $\begin{array}{c}\text { Y } \\
\text { Pos }\end{array}$ & Area & $\begin{array}{c}\text { Area } \\
(\%)\end{array}$ & $\begin{array}{c}\text { Height } \\
(\mathbf{m ~ m})\end{array}$ & $\begin{array}{c}\mathbf{R}_{\mathbf{f}} \\
\text { values }\end{array}$ \\
\hline 1 & 11.3 & 4574.87 & 89.1 & 1087.01 & 0.04 \\
2 & 26.3 & 7.94 & 0.2 & 4.52 & 0.22 \\
3 & 33.1 & 53.36 & 1.0 & 13.6 & 0.33 \\
4 & 37.9 & 26.23 & 0.5 & 12.25 & 0.39 \\
5 & 43.5 & 369.85 & 7.2 & 128.73 & 0.47 \\
6 & 51.3 & 17.8 & 0.3 & 6.47 & 0.55 \\
7 & 55.2 & 10.74 & 0.2 & 6.04 & 0.63 \\
8 & 59.3 & 8.90 & 0.2 & 3.72 & 0.66 \\
9 & 75.5 & 10.62 & 0.2 & 7.91 & 0.90 \\
10 & 79.4 & 76.74 & 1.5 & 35.60 & 0.93 \\
\hline
\end{tabular}

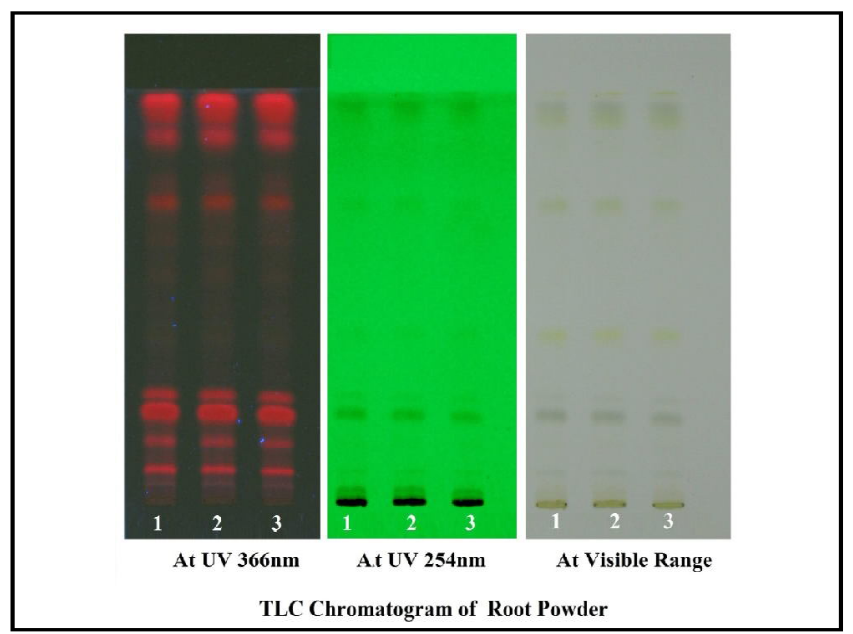

Figure 12: TLC chromatogram of the root powder.

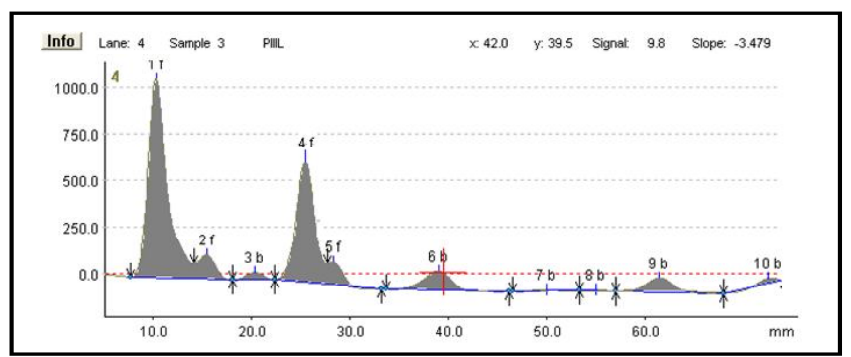

Figure 13: Densitogram showing the separation of peaks of root powder. 
Table 8: Peak list and densitogram of root powder of $M$. nudicaulis at $366 \mathrm{~nm}$ UV light with $R_{\mathrm{f}}$ values of the spots

\begin{tabular}{|c|clc|cc|}
\hline $\begin{array}{c}\text { Peak } \\
\text { No. }\end{array}$ & $\begin{array}{c}\mathbf{Y} \\
\text { Pos }\end{array}$ & Area & $\begin{array}{c}\text { Area } \\
(\boldsymbol{\%})\end{array}$ & $\begin{array}{c}\text { Height } \\
(\mathbf{m m})\end{array}$ & $\begin{array}{c}\mathbf{R}_{\mathrm{f}} \\
\text { values }\end{array}$ \\
\hline 1 & 10.4 & 2384.69 & 50.5 & 1050.93 & 0.00 \\
2 & 15.5 & 265.55 & 5.6 & 129.56 & 0.09 \\
3 & 20.2 & 76.23 & 1.6 & 37.92 & 0.16 \\
4 & 25.5 & 1161.75 & 24.8 & 680.57 & 0.21 \\
5 & 28.2 & 192.15 & 4.0 & 124.25 & 0.27 \\
6 & 39.1 & 326.01 & 6.9 & 104.76 & 0.43 \\
7 & 50.2 & 21.14 & 0.5 & 5.56 & 0.56 \\
8 & 55.2 & 5.0 & 0.1 & 2.79 & 0.64 \\
9 & 61.4 & 230.67 & 4.9 & 71.98 & 0.75 \\
10 & 72.4 & 51.75 & 1.1 & 26.55 & 0.88 \\
\hline
\end{tabular}

\section{Discussion}

In the present context, as we know that traditional remedies used in AYUSH systems-Ayurveda, Siddha and Unani, play a vital role in healthcare systems, as these drugs are easily available at low cost, safe and most of the people have faith in them. The ancient Ayurvedic physicians are considered to have developed the different treatment procedure after validating the therapeutic benefits of the medicinal plants/drugs in humans by the 'hit and trial' method, and the success or failure of the cases being discussed with other eminent scholars during the regional gatherings. However, due to lack of established botanical nomenclature system at that time, these plant origin drugs were documented with their Sanskrit names. Later, Ayurvedic scholars from various places appear to have interpreted their botanical identification in different ways. Multiple pharmacological activities attributed to a single plant origin drug may have complicated the practice of determining the correct botanical scientific name (Husain, 2017).

As the usage of these drugs has increased nowadays, issues related to their quality, safety, and efficacy is of great concern. The purpose of pharmacognostical studies and standardization of medicinal plant products (drugs/formulation) is obviously to ensure the therapeutic efficacy of the end product without any adulteration. Therefore, maintaining the quality of the plant origin drug and its products is an essential factor. The observations on different important parameters revealed some specific results for the drug plant, $M$. nudicaulis, which clearly differs from the other botanical sources of Parpataka like; Peristrophe paniculata, Fumaria indica, Polycarpaea corymbosa, Mollugo cerviana, Glossocardia bosvallea and Rungia repens (Jyothi et al., 2020; Jyothi et al., 2019; Jyothi et al., 2010-1; Jyothi et al., 2010-2; Jyothi et al., 2015).

The presence of various phytochemicals in $M$. nudicaulis plant is in agreement with the similar results reported earlier from the other species such as: Amorphophallus smithsonianus (Kavalan et al., 2020), Aegle marmelos (Tiwari et al., 2016) and Solanum xanthocarpum (Bhatt et al., 2019). Nevertheless, in the present study, due to the solubility nature of a large range of polar compounds, methanolic solvent has been used to extract important phytochemicals from $M$. nudicaulis plant. The methanolic extracts revealed the presence of major phytochemicals such as: alkaloids, saponin, tannin and flavonoids as compared to aqueous extracts. The observation is in consonance with an earlier report on the leaves of Abrus precatorius (Modi et al., 2018).

HPTLC is an important tool which is used for the standardization of the product by the development of fingerprint profile, quantification of phytoconstituents and determination of impurities. It is being used for both qualitative and quantitative analysis of all range of AYUSH formulations and more specifically the crude drugs. HPTLC analysis and validation of markers compounds plays a major role in standardization of poly herbal formulation (Thakur et al., 2020).

\section{Conclusion}

The study on $M$. nudicaulis successfully established the pharmacognostical standards of a market sample drug, Parpataka. The morphological, microscopical, physicochemical and chromatographic parameters of this controversial drug would surely help to identify the species and would also be proved to be helpful in determination of its purity and quality standards during the preparation of Ayurvedic formulations. Further, these data could be utilized amicably in evaluation of pharmacopoeial measures and adulteration, in terms quality assurance of drug with cost effective and less time-consuming technique like HPTLC.

\section{Acknowledgements}

The authors are thankful to the Department of Botany, S.V University, Tirupati and Director General, Central Council for Research in Unani Medicine (CCRUM), New Delhi for necessary encouragement and support.

\section{Conflict of interest}

The authors declare no conflicts of interest relevant to this article.

\section{References}

Anonymous (1962). The Wealth of India (Raw material) Vol. V-VII. C.S.I.R. New Delhi.

Anonymous (1978). The Ayurvedic Formulary of India. Part-I Controller of Publications, New Delhi.

Bapalal, V. (1985). Some controversial drugs in Indian Medicine, Choukambha, Varanasi, pp:33,45,56.

Bhatt, P.R.; Patel U.D.; Modi, C.M.; Pandya, K.B. and Patel, H.B. (2019). Thinlayer chromatography and in vitro free radical scavenging activity of few medicinal plants from the surroundings of Junagadh, Gujarat, India. Ann. Phytomed., 8(1):45-55. DOI: 10.21276/ap.2019.8.1.5

Chunekar, K.C. (1999). Plants of Bhava Prakasa, National Board of Ayurveda, Ministry of Health and Family Welfare, New Delhi, pp:55.

Gamble, J.S. (1936). Flora of the Presidency of Madras, (Reprinted Ed.) Vol I-III, Allard and Co., London, Botanical Survey of India, Calcutta.

Harbone, J. (1973). Phytochemical methods: A guide to modern techniques of plant analysis. Published by Chapman and Hall, an imprint of Thomson Science, 2-6 Boundary Row, London SE18HN, UK.

Husain, M.K. (2017). Botanical identification of Ayurvedic single plant drugs and role of plant tissue culture in ex-situ conservation of rare and endangered plants. Proceedings of the CME-2017, PG Department of Dravyaguna, Dr. BRKR Ayurvedic Medical College, Hyderabad and Rashtriya Ayurveda Vidya-peeth, New Delhi. 
Johansen, D.A. (1940). Plant micro-technique. McGrow Hill, New York.

Jyothi, B.; Pratap, G.P.; Husain, M.K.; Swamy, D.M.; Prasad, G.P. and Sudarsanam, G. (2020). Standardization of parpataka (Peristrophe paniculata) An ayurvedic drug. Int J Pharm. Sci. Res., 11(2):811-19. doi: 10.13040/IJPSR.0975-8232.11(2).811-819.

Jyothi, B.; Pratap, G. P.; Husain, M. K.; Kazmi, M. H.; Prasad, G. P. and Sudarsanam, G. (2019). Scientific validation and standardization of parpataka an Ayurvedic drug with respect to Fumaria indica. Int. J. Curr. Pharm. Sci., 11:134-141.

Jyothi, B.; Sudarsanam, G.; Sitaram, B. and Babu, G.P. (2010-1). Pharmacognosy of a local market sample of parpataka Polycarpaea corymbosa (L.) Lam. Int. J. Plant Sci., 5(2):613-619.

Jyothi, B.; Sudarsanam, G. and Sitaram, B. (2010). Pharmacognosy of a local market sample of Parpataka Mollugo cerviana (L.) Ser. Phcog. Net., 2(8):233-239.

Jyothi, B.; Sudarsanam, G. and Pratap, G.P. (2015). Pharmacognostical standardization on leaves, stem and roots of Glossocardia bosvallea (L.f.) DC. Int. J. Pharm. Bio. Sci., 6(4):682-694

Jyoti, P.; Ankita. K.; Hemali, P. and Sumitra, C. (2018). Physicochemical, phytochemical and pharmacognostic evaluation of a halophytic plant, Trianthema portulacastrum Int. J. Curr. Microbiol. App. Sci., 7(5):1486-1502.

Kavalan, R.; Abdussalam, A. K. and Gothandam, K. M. (2020). Phytochemical evaluation of Amorphophallus smithsonianus Sivad.: A rare endemic species from Western Ghats, Kerala, India. Ann. Phytomed. 9(2):271-276. http://dx.doi.org/10.21276/ap.2020.9.2.26

Kirtikar, K.R. and Basu, B.D. (1987). Indian medicinal plants. Prashant Gahlot at Valley Offset Printers and Publishers, Dehradun, Uthranchal, Voll-II, pp:1186.

Kumari, T.; Pratap,G.P.; Murthy, P.H.C. and Prasad, G.P. (2020). Pharmacognostical standardization of balamula churna (Sida acuta f. root powder). Int. J. Res. Pharm. Sci., 11(1):160-165. doi: https://doi.org/10.26452/ijrps.v11i1.1801

Lakshmipati, A. (1973). One hundred useful drugs, Arogya Ashrama Samithi, Madras. Vol. III, pp:89.

Modi, C.M.; Ladumor, V.C.; Patel, U. D.; Patel, H.B.; Solanki, S. L. and Bhadarka, D.H. (2018). Phytochemical analysis and comparative study of in vitro free radical scavenging activity of different extracts of leaves of Abrus precatorius L. Ann. Phytomed., 7(2):133-137. DOI: 10.21 276/ap.2018.7.2.21

Nadkarni, A.K. (1996). Indian materia medica, Bombay, Vol. I, pp:108.

Ngameni, B.; Fotso, G.W.; Kamga, J.; Ambassa, P.; Abdou, T.; Fankam, A.G.; Voukeng, I.K.; Ngadjui, B.T.; Abegaz, B.M. and Kuete, V. (2013). 9 - Flavonoids and related compounds from the medicinal plants of Africa. Medicinal Plant Research in Africa. Oxford: Elsevier, pp:301-350. https://doi.org/10.1016/B978-0-12-405927-6.00009-6

Pande, J.; Padalia, H.; Donga, S. and Chanda, S. (2018). Pharmacognostic, physicochemical and phytochemical studies of Andrographis echioides and Tridax procumbens L. leaf and stem. The Pharma Innov. J., 6:303-315.

Poumale, H.M.P.; Hamm, R.; Zang, Y.; Shiono, Y. and Kuete, V.(2013). 8 - Coumarins and related compounds from the medicinal plants of Africa. In: Kuete V, editor. Medicinal Plant Research in Africa. Oxford: Elsevier. pp:261-300.

Pratap, G.P.; Sudarsanam, G. and Prasad, G.P. (2014-1). Microscopical observations on Cissus vitiginea Int. J. Ayur. Pharma. Res., 2(4):4758. https://ijapr.in/index.php/ijapr/article/view/225

Pratap, G.P.; Sudarsanam, G. and Hussain, M. K. (2014-2). Physicochemical, preliminary phytochemical and antibacterial investigation on leaves of Cardiospermum canescens Wall. Int. J. Pharm. Bio. Sci., 5 (1):1088-1095.

Pratap, G.P.; Sudarsanam, G. and Prasad, G.P. (2012). Pharmacognostical and analytical studies of leaves of Cardiospermum canescens Wall. Int. J. Phytomed. 4(3):389-394.

Rangacharyulu, D. (1991). Floristic studies of Chittoor district, Ph.D. thesis, S.V. University, Tirupati, India.

Sudarsanam, G. (1987). Ethnobotanical survey and phytopharmacochemical screening of selected medicinal plants of Chittoor district, Andhra Pradesh Ph.D Thesis, S.V. University, Tirupati, India.

Thakur, K.; Mol, M.P.; Madhuree, G.; Gupta, H.; Patil, P.; Salmani, S. and Thakur, M. (2020). Physicochemical characterization and antimicrobial properties of Mahamanjishthadi kadha: An Ayurvedic formulation. Ann. Phytomed., 9(1):78-90. http://dx.doi.org/10.21276/ap.2020. 9.1.

Tiwari, B.; Abidi, A.B.; Rizvi, S. I. and Pandey, K. B. (2016). Phytochemical screening and evaluation of antioxidant potentials of some Indian medicinal plants and their composite extract. Ann. Phytomed., 5(1):99-103

Wansi, J.D.; Devkota, K.P.; Tshikalange, E. and Kuete V. (2013). 14-alkaloids from the medicinal plants of Africa. In: Kuete V, editor. Medicinal Plant Research in Africa. Oxford: Elsevier. pp:557-605.

Yadav, R. and Singh, M.V. (2018). The pharmacognostical studies of Berberis aristata Int. J. Green Pharma., 12(2):148-152.

Yoganarasimhan, S.N. (2000). Medicinal Plants of India, Tamil Nadu, cyber media publishers, Bangalore, Vol. 2, pp:262, 358, 430, 472.

Goli Penchala Pratap, Brahmanapalle Jyothi, Mohd. Kashif Husain, Vallepu Nagaraju and Gudivada Sudarsanam (2021). Pharmacognostical and phytochemical studies of Mollugo nudicaulis Lam.: A controversial plant origin ayurvedic drug. Ann. Phytomed., 10(2):44-52. http://dx.doi.org/10.21276/ap.2021.10.2.5 